\title{
Cultivate Students' Innovation Ability in English Teaching
}

\section{$\mathrm{Na} \mathrm{Li}$}

\author{
(Jiangxi Science \& Technology Normal University, Nanchang, 330038)
}

\section{Keywords: Innovation ability, Subjectivity, Divergence creation}

\begin{abstract}
English teaching emphasizes training students' ability, imitating and reciting book knowledge, and ignores cultivating students' thinking ability, analytical ability and the ability to put forward their own opinions, which causes students lack learning autonomy and originality. Language is a communication tool with the role to improve thinking and ability. On the basis of summarizing the domestic and foreign literatures on network language teaching, creativity, creative thinking ability and innovation attitude, this paper studies the creative thinking ability and innovative attitude of college English teaching based on the related theories of online English teaching and creative thinking. The author analyzes the changes of creative thinking and innovation attitude of students under the teaching of network assisted language and the traditional language teaching and compares the similarities and differences between male and females' creative thinking ability and innovative attitude.
\end{abstract}

\section{Introduction}

With the full implementation of the new curriculum reform, English teaching has entered a new stage of exploration. The new curriculum reform requires educators to be based on quality education and concern about the overall development of all students and train the new talents needed in the society. It is important as whether future talents have a strong spirit of innovation, explorative and practical ability with independent learning and self-development. Only with these capabilities, students can take an invincible position in social development. However, English teaching in many schools is still wandering on the old way of examination-oriented education, the traditional teaching methods still dominate, some teachers only focus on students' mechanical memorizing and are desperately engaged in "question sea" in the pursuit of the only standard answer, but ignore students' spirit of innovation and the cultivation of practical ability. This traditional teaching model greatly limits the development of students' cognitive ability, participating ability and cooperative ability, so that students cannot expand their knowledge ken nor improve comprehensive usage capacity, resulting in that language, which originally the tool for communication, becomes deaf and dumb dead symbols.

\section{Innovation Education}

It is difficult to define the concept of innovation education. From a broad perspective, the author agree that "innovation education is a kind of education targeting at cultivating pioneering personality, based on comprehensive development of individual comprehensive quality with improving individuals' life quality as the theme so as to improve the quality and competitiveness of the entire nation". The concepts of "innovation education, creative education, entrepreneurship education and innovative talents" are similar in meaning, and their contents are interconnected and can be used interchangeably. From a rigorous academic research point of view, there is still a difference between them, in use should pay attention. Limited to the object and scope of this study, in my opinion, innovation education is quality education that takes cultivating middle school students' innovative quality as the focus and the basic value orientation is to lay a foundation for students to become innovative talents. Innovation education belongs to the category of quality education and is the specification and deepening of quality education as well as the ultimate goal and core of quality education. The fundamental task of innovation education is to cultivate students' innovative spirit, innovation ability and innovative personality, lay a broad and deep foundation for 
cultivating high-level innovative talents, and enhance the national innovation ability and enhance the national innovation ability and services.

\section{Optimize English Teaching and Give Birth to Innovation Quality}

Innovation quality is not abstract and empty, but it has specific contents and specific carriers. The formation and development of innovation ability must have a long and tortuous process, especially the cultivation and improvement of innovation ability is inseparable from necessary and appropriate training and enhancement. Besides, innovation education is not a course, but a kind of quality education with training students' innovative spirit, innovative ability and innovative personality as the basic value orientation. It is reflected on the educational thought and education concepts throughout the entire English teaching process. It is infiltrated in various educational activities (mainly English communication activities) and must be realized relying on reforming the current education thought, education contents and education methods. The classroom is the most important time and space environment for innovation education. Therefore, teachers must optimize the practical teaching of English, use innovative teaching mode and teach students to learn English in a creative manner with the help of modern teaching media. Besides, teachers need to teach students to learn and communicate and finally achieve innovative learning. Innovative communication is the highest level. It is necessary to optimize the teaching of English according to the teaching principle proposed by Bubensky, focus on the purpose and requirements of English teaching, and keep the goal and task of cultivating innovative quality, combining with the characteristics of teaching content and the actual level and development of students, English teaching objectives, content, process, methods and means to achieve the English teaching and innovative education of the double harvest.

Optimize teaching objectives. Mainly to consider the determination of teaching objectives, it is necessary to follow the provisions of the syllabus, closely linked to the provisions of the textbook to complete the overall objectives, highlight the basic objectives, adjust some of the objectives (mainly refers to those who are not suitable for the actual level of students and innovation Quality training objectives and tasks) to fully take care of the acceptability of students, the appropriate increase in the quality of the goal of innovation. At the same time, it is possible to adjust the classification target.

Optimize teaching content. First of all, it is necessary to comprehensively, thoroughly and meticulously analyze the contents of teaching materials. Under the premise of ensuring the basic knowledge teaching and basic skills training of English, we can fully exploit all the materials that can be used to cultivate innovative quality. And those on the "double base" and the role of little innovation, to boldly dilute or even discarded. Second, take into account the fun and scientific nature. In particular, under the premise of creativity, supplement a large number of listening, speaking, reading and writing materials with innovative and innovative personality contents, mainly reading materials.

\section{Strategies to Cultivate Students' Innovation Quality in English Teaching}

The cultivation of students' innovative quality in English teaching should adhere to the guiding ideology of innovative education. It is the requirement for teachers to integrate innovative education into English teaching, and the cultivation of innovative quality is dissolved in all aspects of English teaching. Teachers should cultivate students' innovative spirit, innovative ability and innovative personality as the basic value orientation of English quality education. And it is reflected in the educational ideas and teaching ideas, the main channel of English classroom teaching, the implementation of lesson preparation, teaching, counseling, homework correction, testing, evaluation and extra-curricular activities, such as teaching links.

\section{Stimulate Innovation Wit and Create an Innovative Atmosphere}

Students are the main body of thinking, teachers should always put the students' thinking "in the classroom teaching center," design thinking, guide thinking, encourage thinking, deep thinking ", to 
promote students to improve the ability to innovate, so that students from the same source of materials or information to explore different answers, to cultivate students positive thinking ability. For example: Give the cactus a lot of water once a month. What will happen? Why? Students express their views, speak their minds and give a variety of answers: 1 . it will die because it needs a lot of water. In the timely use of the discussion can stimulate thinking, ignite the spark of students thinking, so that students can explore novel ideas of a problem from different angles, put forward different views, so as to mobilize students to actively participate in activities to create a creative atmosphere.

\section{Give Play to Students' Subjectivity and Stimulate Students' Desire for Exploration}

Quality education is the education to train talents in the $21^{\text {st }}$ century. Students should be the main body of classroom learning activity, and the subjective classroom teaching should have the participation of both teachers and students with multilateral activity of mutual exchanges and teachers and students should maintain an equal, democratic and cooperative relationship so as to make the classroom more open, free and situational, which is beneficial for students to take the initiative to participate. In English classroom teaching, teachers can adopt various means to guide and motivate students to take the initiative to participate, make innovation, arouse students' desire for exploration and cultivate their ability to independently obtain knowledge and creatively use knowledge.

\section{Cultivate Divergent Thinking and Develop Innovation Potential}

Mr. Ye Shengtao advocated the teacher "will enable students to transport their talents, diligent their practice, comprehend the source of open, skilled power deep", discussion, questioning teaching is conducive to divergent thinking, innovative thinking development. To enable students to enrich the imagination, and actively explore the differences and adhere to independent insights, which requires teachers to be good at digging the creative elements contained in teaching materials, through the creation of scenarios, give each student the opportunity to participate, so that students actively use what Knowledge, boldly divergent creation.

\section{Conclusion}

This paper focuses on the strategies that should be taken to cultivate students' innovative quality in English teaching. It puts forward that the basic guiding ideology of infiltration and innovation education should be followed in English teaching. We must follow the basic rules of English teaching and the basic law of innovative education. Optimize the teaching environment, create an innovative atmosphere, and optimize English teaching and English communication to form, develop and improve the quality of students' innovation. This paper also analyzes the two practical teaching modes of infiltration and innovation education: heuristic teaching, discussion teaching, active teaching and research teaching, and sums up three basic principles that should be followed in practical teaching: student subjectivity, carrying forward personality principles; teacher-led, demonstration and innovation principles; comprehensive training, the principle of highlighting focus; comprehensive practice, step by step principle; target incentive, evaluation and strengthening principles. The above research is the initial result of my study, practice and research, and it is also the result of the absorption of experts and colleagues.

\section{References}

[1] Manan S A, David M K, Dumanig F P. English Language Teaching in Pakistan: Language Policies, Delusions and Solutions[J]. 2016.

[2] Zou B, Li J. Exploring Mobile Apps for English Language Teaching and Learning.[J]. Research-publishing.net, 2015.

[3] Baker W. Culture and language in intercultural communication, English as a lingua franca and English language teaching: points of convergence and conflict[J]. 2016.

[4] Kukulskahulme A, Norris L, Donohue J. Mobile pedagogy for English language teaching: a guide for teachers[J]. 2015. 
[5] Zou B, Li J. Exploring mobile apps for English language teaching and learning[C]// Eurocall. 2015:564-568.

[6] Lengeling M M. Ambiguities and Tensions in English Language Teaching Portraits of EFL Teachers as Legitimate Speakers[J]. International Multilingual Research Journal, 2015, 47(2):150203212126002.

[7] Nawel. Reflective English Language Teaching: Exploring our own classroom practice[J]. 2015.

[8] Khezrlou S. Review: Innovations in Learning Technologies for English Language Teaching[J]. Relc Journal, 2015.

[9] Yastibas A E, Cepik S. Teachers' Attitudes toward the Use of e-portfolios in Speaking Classes in English Language Teaching and Learning $\lesssim[\mathrm{J}]$. Procedia - Social and Behavioral Sciences, 2015, 176:514-525.

[10]Harwood N. English Language Teaching Textbooks[J]. ELT Journal, 2015, 69(1):100-102.

[11]Hawanti S. Implementing Indonesia's English language teaching policy in primary schools: The role of teachers' knowledge and beliefs[J]. International Journal of Pedagogies \& Learning, 2015, 9(2):162-170.

[12]Cavalheiro L L. English as a lingua Franca : bridging the gap between theory and practice in english language teaching[J]. 2015. 